\title{
ESTABLISHING AND MAINTAINING MONOCARPIC MECONOPSIS IN LIVING COLLECTIONS
}

\author{
Christopher Grey-Wilson ${ }^{l}$
}

While the large blue-flowered Meconopsis (such as M. betonicifolia) are popular now, it was the large monocarpic species that attracted most attention up until the 1970's. The reasons for the latter's fall from popularity include the fact that they have to be raised from seed each year, the lack of authenticated material, hybridisation in cultivation, climate change and fashion. Ease of hybridisation in cultivation means that it is difficult to maintain authenticated, wildsource material in cultivation and this limits research potential. In this paper the 14 species of subsection Eupolychaetia are briefly described, followed by discussions on building a collection and collecting seeds in the wild. A short description on seed propagation and storage concludes the paper.

\section{INTRODUCTION}

Meconopsis is generally regarded as the connoisseur genus in the poppy family, Papaveraceae, and those who are able to grow them well cherish them with unabashed zeal. Of course it is the large blue-flowered perennial species (Meconopsis betonicifolia and M. grandis, in particular) and their associated hybrids and cultivars that have attracted most attention in recent years, perhaps rightly so, for they are amongst the most magnificent hardy border perennials. Not everyone can grow them: they are plants for cool temperate gardens with a plentiful supply of rain, especially during the summer months.

\section{MONOCARPIC SPECIES}

However, when Meconopsis first started coming into cultivation from Asia in the latter part of the nineteenth century, it was then the large and imposing monocarpic species that attracted most attention and these were quite widely grown up until the 1970s, being less in favour today. The reasons for this are not hard to find:

1. Being monocarpic they die after flowering and fruiting and have to be constantly raised from seed in order to maintain them in cultivation.

2. A lack of good authenticated wild source material coming into cultivation, this being made worse by regional strife and inaccessibility in the areas in which they tend to grow.

${ }^{1}$ Christopher Grey-Wilson was a Principal Scientific Officer at the Royal Botanic Gardens Kew and is now an author and editor of the Alpine Garden Society.

Address: Red Lion Barn, East Church Street, Kenninghall, Nr. Norwich, Norfolk, NR16 2EP

Email:c.grey-wilson@talk21.com 
3. Hybridisation. Most of the species hybridise readily in cultivation, especially when grown in close proximity to one another, and when their peak season of flowering overlap (this is especially true of $M$. paniculata and M. staintonii [M. napaulensis Hort.] but other species can also be involved).

4. Climate change. There is little doubt that as summers become warmer and rainfall more unpredictable, it is increasingly difficult to maintain the large monocarpic species in some regions, especially in the east and south of Britain, although there are notable exceptions where a local microclimate can favour their continuance. In addition, summers are tending to be windier and these plants are very prone to wind damage when they are in full flower unless sited in a very sheltered spot.

5. Fashion. Plants come and go and being 'out of favour' means that they are less readily available than they once were.

From a scientific point of view it is important to maintain authenticated wild-source material in cultivation for future study. Many members of the Papaveraceae have an interesting assortment of alkaloids, some of which (e.g. heroine and morphine) have very significant medicinal value: Meconopsis have scarcely been looked at in this respect. In addition, relatively little DNA work has been carried out on the species. Such studies, combined with morphological and pure taxonomical research would undoubtedly improve our understanding of the genus and the relationship of the various groups and species to one another and to closely related genera like the true poppies, Papaver. Because of the lack of authenticity and the problems with hybridisation in cultivation, serious DNA research can really only be sensibly carried out on authenticated wild-source material: at the present time there is not enough wild-source material in cultivation to allow for meaningful research.

Before considering how these matters can best be resolved it is important to look at the species and their natural distribution. The largest section by far in the genus Meconopsis is Polychaetia Prain (according to George Taylor's 1934 account of the genus) (Taylor, 1934). This in turn is divided into two subsections. The larger subsection is Cumminsia (Prain) G. Taylor which contains only herbaceous species whose leaves die away in the autumn leaving the plant overwintering as a single bud or a cluster of buds at or just beneath the soil surface; they can be monocarpic or truly perennial (polycarpic). This subsection includes a number of well-known garden plants such as M. betonicifolia Franch, M. grandis Prain, M. integrifolia (Maxim.) Franch. and M. pseudointegrifolia Prain, as well as M. prattii (Prain) Prain (M. horridula Hort.), M. punicea Maxim. and M. quintuplinervia Prain.

The second subsection, Eupolychaetia G. Taylor, contains only the monocarpic, evergreen species of Meconopsis. Some of these are the largest species in the genus, attaining $2 \mathrm{~m}$ or more in height in flower, and they may carry in excess of 150 blooms, which open in succession. All the species in this subsection have handsome over-wintering leaf rosettes and these provide part of their attraction in cultivation. Indeed, when they first came into cultivation (from about 1863 onwards) the eye-catching leaf-rosettes 
were considered almost more important than the flowers and beds of different species were laid out at the Royal Botanic Gardens, Kew, and elsewhere. Well grown specimens of species like M. paniculata can develop rosettes up to $1 \mathrm{~m}$ across in cultivation, although in the wild half that size would be more likely. The rosettes vary in colour from silvery to grey, blue-green and various shades of green and, in the autumn, some take on delightful russet hues which enhances their appeal still further.

Most of the species possess a bold paniculate or semi-paniculate inflorescence, although in some it is a simple raceme. The uppermost flower in the inflorescence opens first, followed by those below, in orderly procession, with those at the end of a lateral branch also opening before those beneath.

The species form an increasingly large rosette after the first year, rarely behaving as a biennial and generally flowering between the third and the fifth year from seed. All the species bear varying degrees and sizes of barbellate hairs which can feel very bristly in coarser individuals. This indumentum, so characteristic of the subsection, envelops leaves, stems, bracts, pedicels, sepals and fruits to varying degrees, indeed all parts of the plant except the roots and petals. In some species this indumentum is underlain by a 'felt' of much shorter hairs. It is a combination of leaf and fruit-capsule characteristics and indumentum, with flower colour to a lesser degree, that defines the species in Eupolychaetia.

The subsection is distributed mainly in the monsoon-rich regions of the Himalaya with one species (M. wilsonii Grey-Wilson) being restricted to western China and north Myanmar.

Subsection Eupolychaetia was revised in 2006 (Grey-Wilson, 2006) and contains 14 species. In alphabetical order these are as follows:

Meconopsis chankheliensis Grey-Wilson. A very little-known species most closely related to $M$. dhwojii and $M$. gracilipes but immediately distinguished by its purple to dull dark red flowers. Unlike $M$. dhwojii the leaf bristles lack a dark base, while from $M$. gracilipes it also differs in it hairier, more acutely lobed leaves. Endemic to west Nepal (Jumla District) at 3200-4575m. Described in 2006 from material collected in 1952 by Polunin, Sykes \& Williams; not in cultivation.

Meconopsis dhwojii G.Taylor. A small plant to $600 \mathrm{~mm}$ tall in flower with distinctive rosettes of rather dense, petiolate, finely dissected leaves to $330 \mathrm{~mm}$ long, these greygreen, but often flushed with purple, especially during the winter, the leaves covered in rather sparse, simple bristles which have a characteristic purple-black base. Inflorescence a cone-shaped, many-flowered panicle, with cup to saucer-shaped flowers, the petals creamy-yellow. Fruit capsule ellipsoidal, 20-41 mm long with spreading simple bristles. Endemic to central east Nepal (Rolwaling Himal) at 3660-4725m. Well established in cultivation since the 1950s and not known to hybridise with other species.

Meconopsis ganeshensis Grey-Wilson. Rather similar to M. napaulensis in overall dimensions and distinguished most easily on account of its dark red to pinkish-red 
flowers. In addition, the indumentum consists solely of slender bristles without an underlay. Endemic to central Nepal (Ganesh Himal) at 3658-4040m. Not in cultivation and probably never introduced.

Meconopsis gracilipes G.Taylor. An elegant and rather graceful species to $1 \mathrm{~m}$ tall forming small, lax leaf-rosettes with a lax scattering of simple bristles (these often breaking off at maturity to leave a stubbly base), the basal leaves generally withered at flowering time. The inflorescence is subpaniculate with long, slender branches, the flowers relatively small and broad bowl-shaped, the petals pale yellow. The fruit capsule is flask-shaped, $18-23 \mathrm{~mm}$ long, 4-6-valved usually, with a covering of rather sparse spreading to deflexed bristles, adorned with a relatively long style. Endemic to Central Nepal (Annapurna, Lamjung and Ganesh Himal) at 2440-3960m. Rather rare in cultivation, but it has not been known to hybridise with any other species.

Meconopsis napaulensis D.C. (Fig. 1) Plant $0.5-1.1 \mathrm{~m}$ tall in flower with long-petioled, pinnnately-lobed leaves to $38 \mathrm{~cm}$ long, covered in long barbellate hairs with a sparse underlay of shorter hairs. Inflorescence semi-paniculate, the flowers deeply cupped, 70-90mm across, with yellow petals. Fruit capsule narrow-obovoid, 26-32 mm long, usually 5-valved, covered with sparse spreading hairs which often snap off near the base at maturity. Endemic to central Nepal (Pulchok and Rasuwa Ditricts) at 3350-4100m. Not in cultivation as far as it is known at the present time and not to be confused with M. napaulensis of horticulture (see M. staintonii).

\section{Meconopsis paniculata (D.Don) Prain. (Fig. 2)} In many ways the yellowflowered equivalent of $M$. staintonii yet, at the same time, a far more widespread and variable species. Plants often reach $2.5 \mathrm{~m}$ tall, although in the wild $1-1.5 \mathrm{~m}$ is more normal. The rosettes can be very large, the leaves to $400 \mathrm{~mm}$ long varying in colour from rather bright yellow or lime-green to bluish-green. The inflorescence is usually paniculate and multi-flowered, although it can be reduced to almost a raceme on occasions. The cupped flowers have

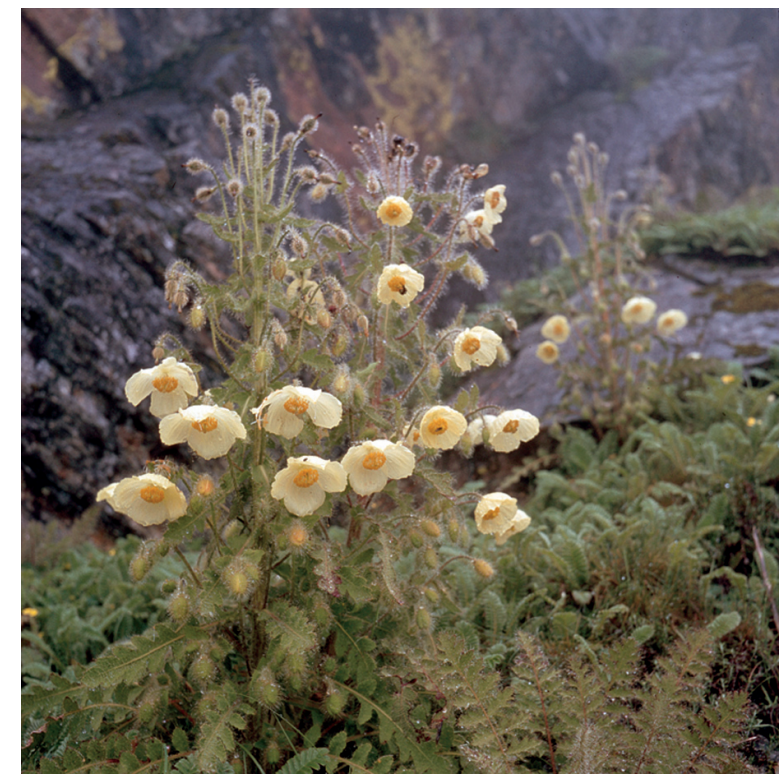

Fig. 1 Meconopsis napaulensis in central Nepal. Photo: Dieter Schacht. 
yellow, sometimes cream to pale primrose, petals with a telltale purple or reddishpurple stigma. The fruit capsule is obovoid to ellipsoid, 18-40mm long, 8-12-valved and thickly covered in ascending bristles. Distributed from western Nepal to north east India (Assam) as well as extreme south Tibet (Xizang) at 3500-4420m. This widespread Himalayan species is very variable and various forms are in cultivation, primarily from modern collections, although it first flowered in cultivation in 1863. Hybridisation in cultivation, which occurs readily with $M$. staintonii and formerly with $M$. regia, has meant that very little material is genuine $M$. paniculata. Hybrids often have rather poorly coloured flowers, pinks and bicolours dominating, while the purple stigma is often lost; however, some hybrids are magnificent, garden-worthy plants.

Meconopsis regia G.Taylor. (Fig. 3) A very distinctive species to $1.75 \mathrm{~m}$ tall with beautifully symmetrical fawn or golden rosettes of elliptical, unlobed leaves to $470 \mathrm{~mm}$ long, thickly covered in simple, soft barbellate hairs without an underlying felt. The narrow paniculate inflorescence bears deeply cupped, half-nodding flowers, 100-130mm across, the petals butter yellow, with a prominent reddish-purple stigma. Fruit capsule oblongellipsoidal, 18-45mm long, 7-12-valved, covered in dense, appressed bristles. Endemic to central Nepal (Gurkha and Lamjung Himal) at 3900-4200m. One of the most beautiful species, widely cultivated at one time but now very scarce in cultivation. Due to hybridisation with other species, notably M. paniculata and M. staintonii: most plants in Britain sold as $M$. regia prove to be of such hybrid origin and lack the crisply toothed, unlobed leaves characteristic of the species.

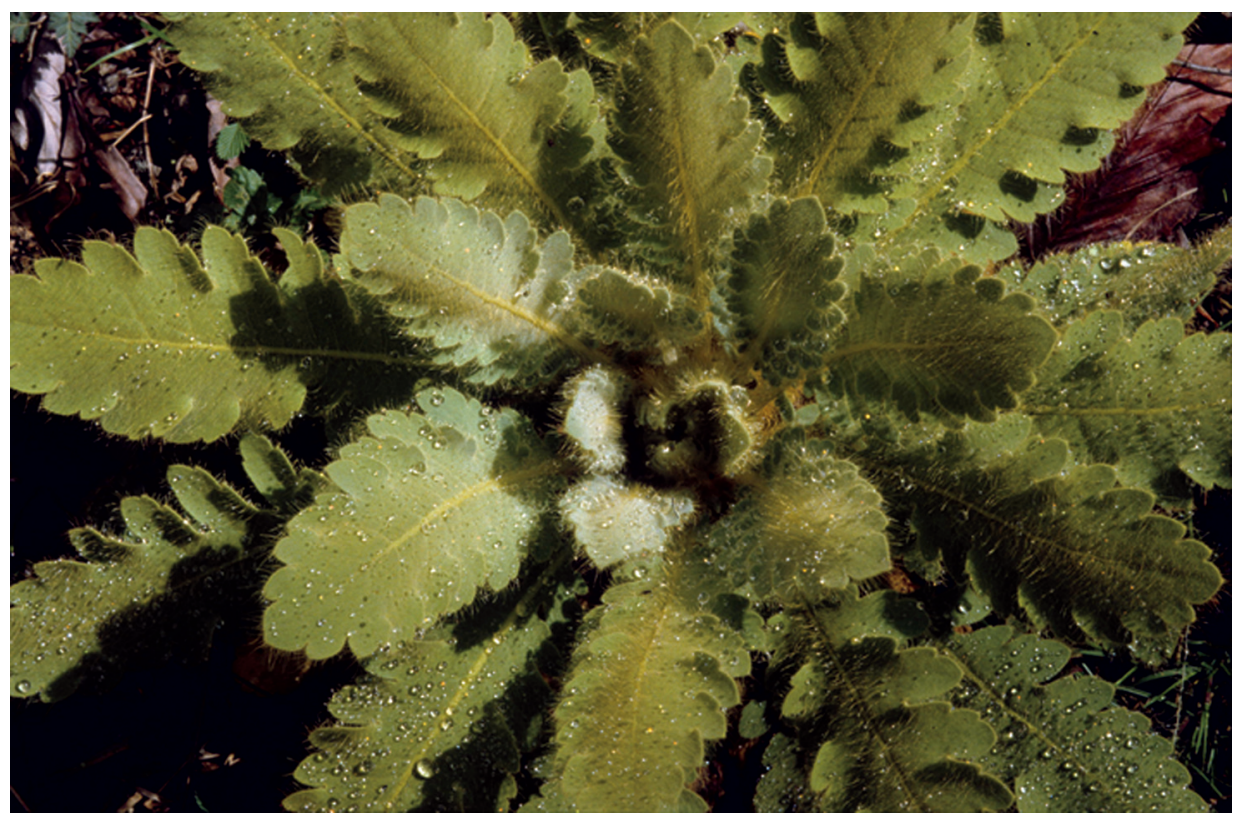

Fig. 2 Meconopsis paniculata in Ghunasa Khola, eastern Nepal. Photo: Christopher Grey-Wilson. 


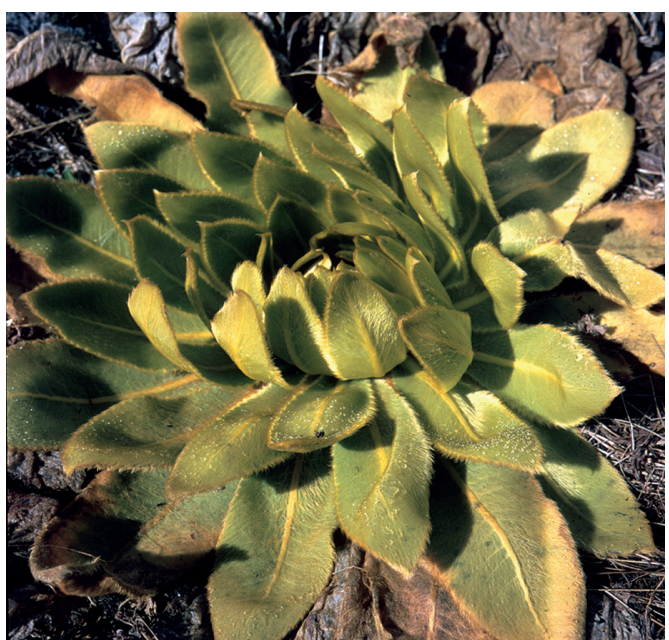

Fig. 3 Meconopsis regia in central Nepal. Photo: Dieter Schacht.

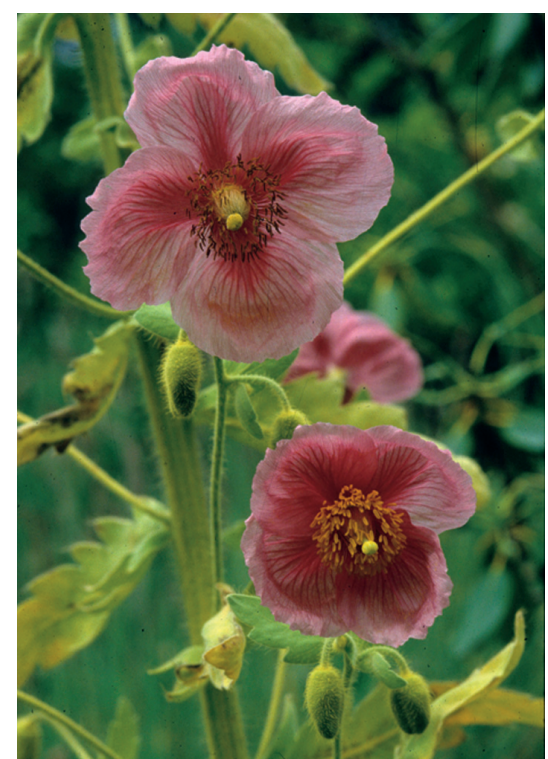

Fig. 4 Meconopsis staintonii in cultivation. Photo: Christopher Grey-Wilson.

Meconopsis robusta Hook. f. A little-known species very similar to M. paniculata, but a generally slighter plant to $1.5 \mathrm{~m}$ with a simple racemose inflorescence and a yellow stigma. The fruit capsule is $18-28 \mathrm{~mm}$ long and 6-9-valved. Endemic to northern India (Kumaon) at 2440-3140m. Occasionally seen in cultivation but most plants found under the name prove to be $M$. paniculata.

Meconopsis staintonii Grey-Wilson. (Fig. 4) A large and imposing plant to $2 \mathrm{~m}$ tall (occasionally $3 \mathrm{~m}$ tall in cultivation), the whole plant covered in golden-brown hairs with a conspicuous underlay of shorter hairs. The leaves are large, to $520 \mathrm{~mm}$ long, pinnately-lobed towards the base. The inflorescence is a large, multi-flowered panicle, bearing nodding cup-shaped flowers with usually deep red petals, although pinkish-red and rarely white have been recorded in the wild. Fruit capsule ellipsoidal to obovoidal, comparatively large, 22-34mm long, 7-10-valved, covered with semi-appressed, golden bristles. Endemic to central Nepal (Annapurna Himal and Kali Gandaki) at 2590-3810m. Certainly cultivated (as M. napaulensis) since before 1831, but plants in cultivation today are probably derived from Stainton, Sykes \& Williams collections of the 1950s, and later collections. Hybridises freely in cultivation with M. paniculata.

Meconopsis superba King ex Prain. (Fig. 5) Closely related to M. superba, but bearing rosettes of silky, silvery rosettes with a velvety sheen, the leaves more oblong, to 360 $\mathrm{mm}$ long, while the flowers are white with a purple stigma. Fruit capsule oblong to ellipsoidal, 36-38mm long, 9-14-valved, covered in appressed bristles. Endemic to central 


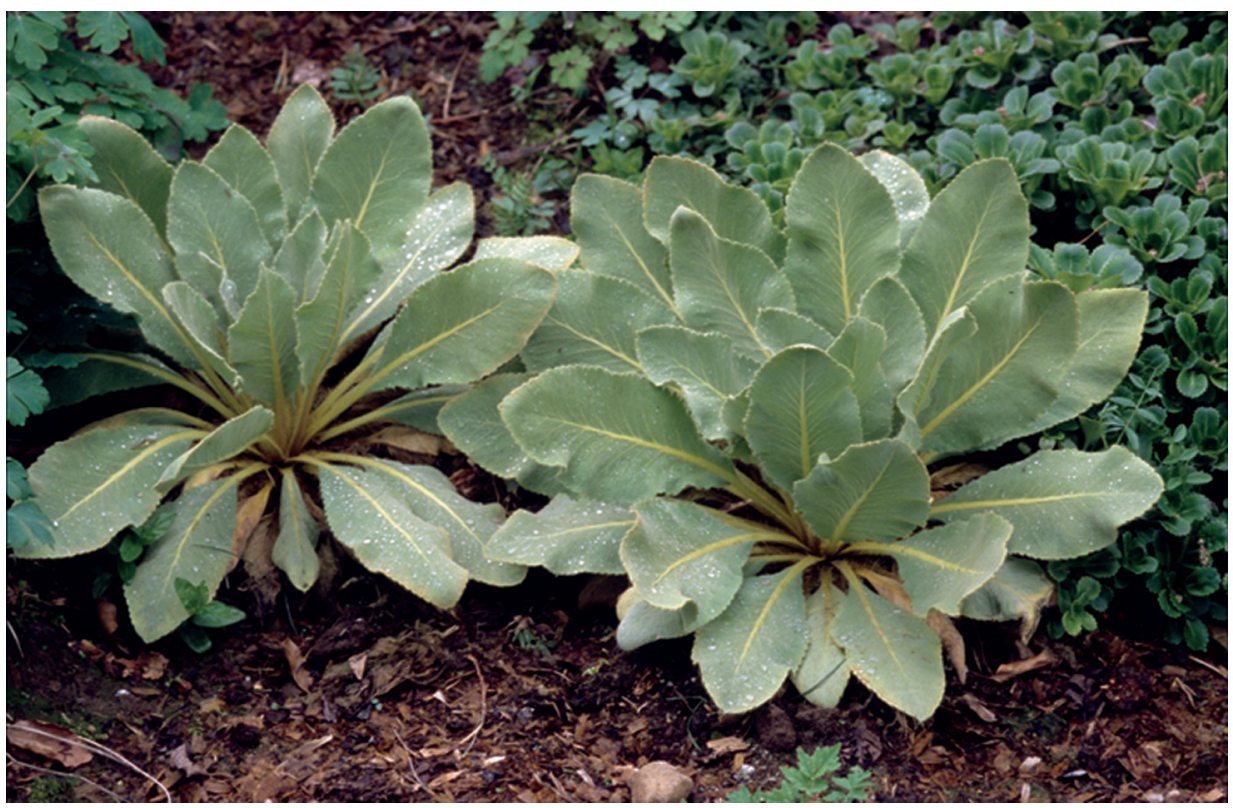

Fig. 5 Meconopsis superba in cultivation. Photo: Christopher Grey-Wilson.

Bhutan at 4100-4250m. Well-established in cultivation and appears not to hybridise with other species.

Meconopsis taylorii L.H.J.Williams. A very distinctive but little-known species to $1.8 \mathrm{~m}$ tall, closely related to $M$. regia but with larger leaves to $600 \mathrm{~mm}$ long with an often rather coarsely toothed margin, covered with straw-coloured bristles with a dense underlay of short hairs, the petiole broadly winged. Inflorescence a broad pyramidal panicle with numerous deeply cupped flowers $55-80 \mathrm{~mm}$ across, the petals pale to deep pink. Fruit capsule very large, oblong-clavate, $35-60 \mathrm{~mm}$ long covered in appressed bristles, these often breaking off in the mature capsule. Endemic to central Nepal (Annapurna Himal) at 3660-4420m. Cultivated for a short while during the 1950s from seed collected by Stainton, Sykes \& Williams but not in cultivation today, indeed only known from the original collections.

Meconopsis violacea Kingdon Ward. A very distinctive and little known species to $1.8 \mathrm{~m}$ tall forming bluish-green rosettes of rather narrow, linear-oblong, zig-zag-lobed leaves, covered in a mixture of short and long barbellate hairs. Inflorescence a simple raceme carrying 12 or more bowl-shaped flowers, these $60-70 \mathrm{~mm}$ across, with bluishviolet petals, contrasting with bright orange anthers. Fruit capsule oblong-ellipsoidal, 33-37mm long, 7-9-valved, covered in bristles on their bases. Endemic to a small region of Upper Burma (Myanmar) and adjacent Tibet (Xizang) at 3050-3965m. Cultivated from Kingdon Ward introductions in the 1920s but no longer in cultivation today. 


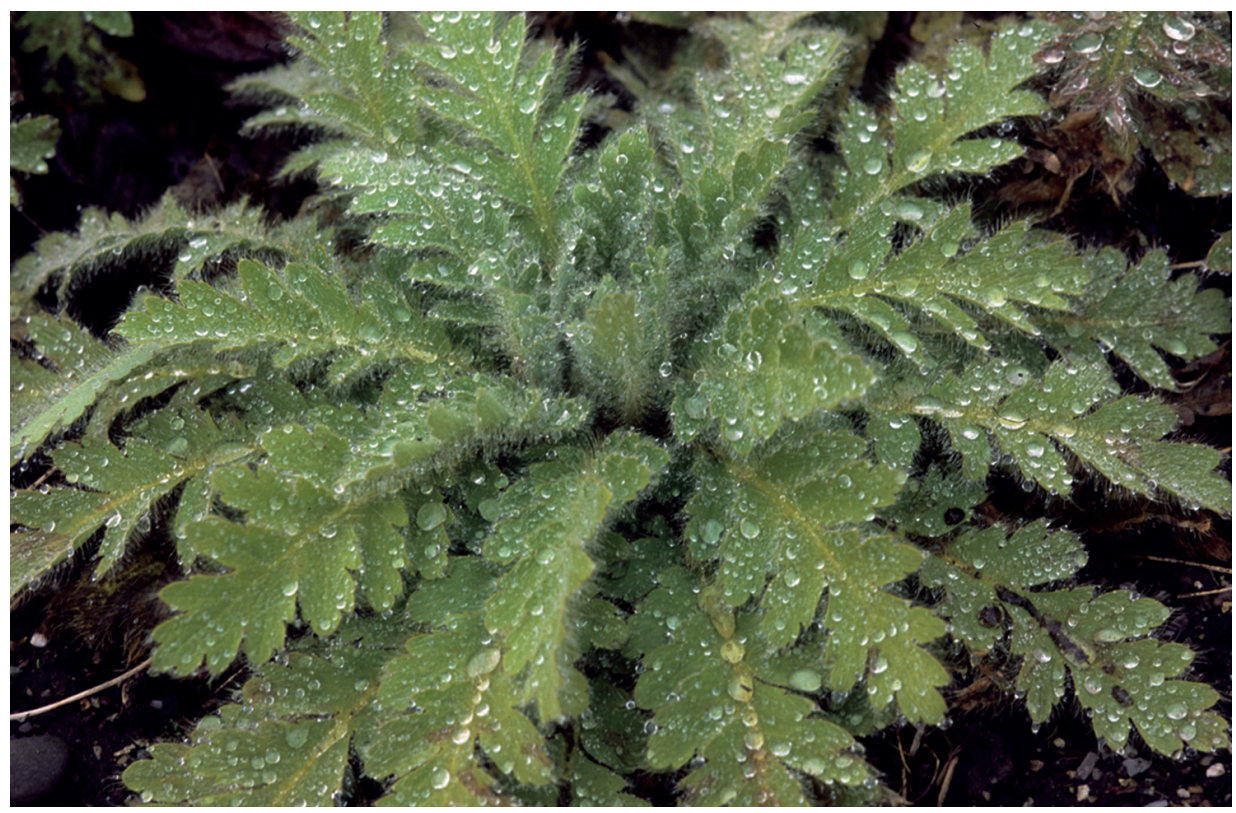

Fig. 5 Meconopsis wallichii in cultivation. Photo: Christopher Grey-Wilson.

Meconopsis wallichii Hook. (Fig. 5) Very like M. staintonii in dimensions but leaves generally more grey-green and with finer dissections. The inflorescence is often larger with the lateral branches bearing up to 15 flowers (not more than 11 in M. staintonii), the petals most often blue, mauve-blue or lavender-blue, but purple, red or whitish with a lilac tint have also been recorded in the wild. The fruit capsule is very different from that of M. staintonii, being flask-shaped with a narrow base, $11-25 \mathrm{~mm}$ long, with spreading bristles. Endemic to east Nepal (Arun Valley eastwards) and Sikkim, eastwards to central Bhutan at 2440-3810m. Well-established in cultivation from collections gathered in the 1960s onwards and being rather later flowering (July-August) than M. napaulensis and M. paniculata hybrids are less likely to occur. The first flowers to open may overlap with the later ones of the other two species; however, seed collected from fruits of the later flowers are likely to be pure. Plants with red or purple-red flowers are assigned to var. fusco-purpurea Hook. f.

Meconopsis wilsonii Grey-Wilson. (Fig. 6) Long confused with M. wallichii, this species is readily distinguished by its markedly grey foliage, fastigiate or semifastigiate inflorescence and purple or wine-purple flowers. In addition, a notable difference is seen in the fruit capsules that are ovoid to ellipsoid, 14-20mm long, generally 5-valved and covered in ascending bristles. Endemic to western and southwestern China (west Sichuan and west \& north west Yunnan) and north Myanmar at 2745-3965m. Rare and comparatively little-known in cultivation, although certainly introduced in collections in the early twentieth century by George Forrest, Ernest Henry 
Wilson and others; however, those in cultivation today are from seed introduced to Britain in the 1990s.

\section{BUILDING A COLLECTION}

Unless material of known wild origin can be authenticated, then collections are of little scientific value, especially those at botanic gardens, but in many ways this applies to any collection. The lack of collecting details (i.e. collector's numbers etc) with most collections outside botanic gardens is a real problem for researchers, especially those undertaken DNA or cytological studies. This applies especially to Meconopsis and the monocarpic species in particular for they cannot be vegetatively propagated. Instead seed is the sole origin of plants and in cultivation and where hybridi-

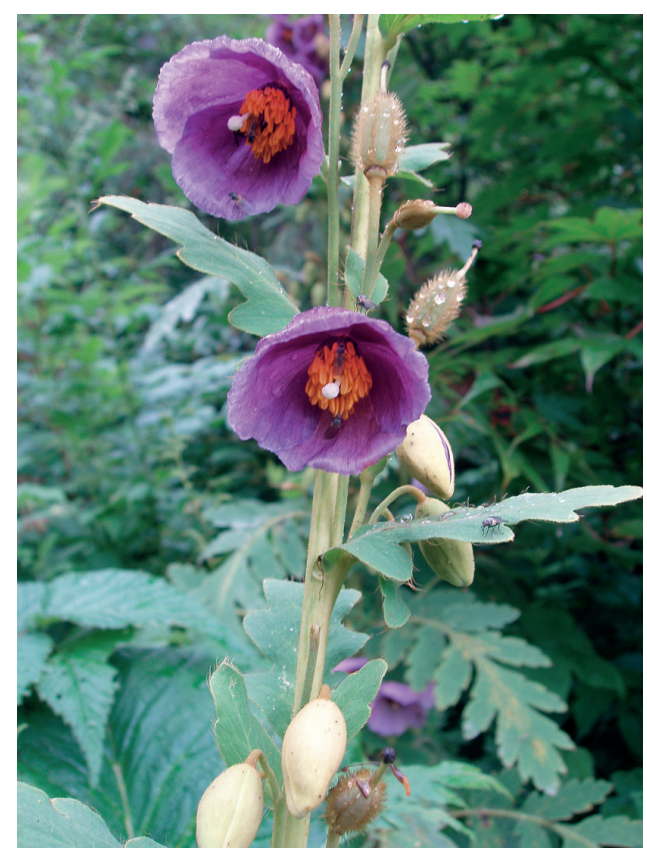

Fig. 6 Meconopsis wilsonii in Yunnan, south west China. Photo: Joe Atkin. sation may have contaminated species' purity it is a real cause for concern; samples used from such plants cannot be used for serious scientific work except to ascertain hybrid origin.

Ideally, all researches using live material should use first generation wild collected material; however, with monocarpic species this is not always possible. In this event species identity can be preserved by isolating cultivated populations so that the risk of contamination/hybridisation is reduced to the minimum. This is easily achieved by keeping a good distance between plantings in botanic gardens or large gardens, or 'farming' out collections to different gardens in order to achieve isolation.

As has already been pointed out certain species hybridise very readily in the garden when grown in close proximity to one another. This applies especially to M. paniculata, $M$. regia and $M$. staintonii and, to a lesser extent (because of its later flowering), to $M$. wallichii and presumably M. wilsonii. However, the possibility of hybrids occurring between any of the species in the Eupolychaetia cannot be ruled out.

\section{COLLECTION OF SEED IN THE WILD}

The monocarpic evergreen species of Meconopsis are handsome and beautiful plants that are a great addition to gardens with moist cool summers. Where permits can be obtained then collecting fresh wild seed is by far the best way to build a collection. The 
fruit capsules of Meconopsis, especially of the Eupolychaetia species contain numerous seeds (some capsules may contain as many as 300 !), so it is easy to acquire adequate seed from fruiting specimens in the wild, especially as plants may have dozens of ripe capsules.

Seed can be readily shaken out of the pepper-pot capsules into dry seed bags and will keep very well for some time. In large populations samples should be taken from as many individuals as possible; however, if it is suspected that populations are mixed with two or more species or possible hybrids in the wild, then seed is best collected and packeted from individual plants separately. One fruit capsule per sample in each seed envelope can be very useful for latter analysis. Enough seed should be collected to supply the needs of the institute or garden as well as passing on samples (together with all the collecting details) to other institutes or gardens. At the same time botanic gardens should ensure that a percentage of each collection is put into a suitable seed bank for future use. This is especially important for annual and monocarpic species in many genera for, if they fail to set seed, then the collection may be lost; however, it can be recuperated by access to the seed bank.

Inaccessibility can hamper renewed collections. Of the fourteen species in the Eupolychaetia only $M$. violacea from the Burmese-Tibet border area, and the western Nepalese $M$. chankheliensis can be considered impossible to collect at the present time for political reasons, while others like the recently described $M$. ganeshensis grow in remote areas which are difficult to access.

Also important is the fact that collecting should not stop because a particular species is in cultivation because researchers (taxonomists in particular), like to access the variability in species and repeated collections from different parts of the range may yield valuable information on variation within that species. At the same time it may also reveal some interesting variants for garden cultivation.

\section{SUMMARY}

The monocarpic evergreen Meconopsis species have suffered a decline in popularity in recent years for various reasons, although the loss of species identity because of hybridisation in gardens has proved a prime cause for this decline. The species are all very beautiful plants which, if properly managed, can be maintained satisfactorily in cultivation. Fresh collections of seed are required from the wild and expeditions and individuals venturing into those parts of the Himalaya and western China where they grow need to be encouraged to collect seed as described above, provided, that is, the necessary collecting permits are in place. There is still a lot to learn about the taxonomy and cytology of these interesting plants and this is best undertaken using authenticated wild source material and this can be supplemented for the taxonomist and botanist at least, by field studies. 


\title{
SEED PROPAGATION AND STORAGE OF MONOCARPIC MECONOPSIS.
}

\author{
John Mitchell ${ }^{2}$
}

Monocarpic Meconopsis are some of the most beautiful plants that it is possible to grow in a garden. They are not to difficult to cultivate but care needs to be taken with species selection due to cross hybridization. For example, M. napaulensis tends to cross with M. paniculata. It is always best to keep monocarpic species apart or, if space is limited, it may be better to try species such as M.horridula, M.delavayi and M.punicea because these species do not hybridize.

At the Royal Botanic Garden Edinburgh (RBGE) we grow a wide range of monocarpic Meconopsis including M. horridula, M. dhwojii, M. superba, M. punicea, M. paniculata, $M$. napaulensis and $M$. integrifolia. All these species require different conditions in which to grow and having the space at RBGE, we can grow these plants in different areas which should hopefully prevent cross pollination.

Once a decision has been made about which species to grow, the next stage involves trying to get the plants to flower so that seed can be collected and to continue growing the species for years to come.

Once the seed capsules have started to open at the top of the seed pod we collect all the capsules and place them in a paper bag with all the plant details, such as the accession number, bed location and, most important, the date and the year of collection. The importance of this will become more relevant when the storage of seed is described.

The seeds are placed in a small tray lined with paper and are cleaned to get remove any unripe seed and other debris. At this stage we are ready to do two things.

First, to ensure that there is enough seed to sow for the next generation of Meconopsis and second, it is also very important to store seeds so that if, in future years, plants do not survive for any reason it is possible to get seed from the seed bank with which to start again.

\section{SEED SOWING}

Meconopsis seed is best sown fresh but can still be sown up until the end of February. In Scotland this can be extended by a month while still obtaining good germination.

Compost should be peat free and at RBGE we use John Innes number 2 with added grit and a portion of leaf mould. This is then soaked and the seed sprinkled evenly over the compost which is then covered with sieved compost and a light covering of fine grit.

\footnotetext{
${ }^{2}$ John Mitchell is Alpine Department Supervisor at the Royal Botanic Garden Edinburgh. Address: 20A, Inverleith Row, Edinburgh, EH3 5LR.

Email: J.Mitchell@ rbge.ac.uk
} 
Watering should always be undertaken from below using a plunge tray as this will not disturb the seed.

The pots are then placed outside in a cold frame and covered with glass to stop heavy rain from disturbing the seed. Also it is important to put the sowing date on the back of the label; this makes it possible to keep a check on the germination times from year to year.

The pots should be checked every day to see if germination has started as this can take from a couple of weeks to several months or, depending on the species, a whole year. Once the seedlings have emerged, they need to be brought into the glasshouse, and at the same time a note of the date that they germinated needs to be made for the plant records.

\section{SEEDLING TRANSPLANTATION}

This is the time when problems occur and attention to detail and good hygiene can really help. At some gardens staff prefer to transplant (prick out) half of the seedlings and wait to see if they develop healthily before doing the remainder. Others prefer to wait until the seedlings are a little bit bigger and then prick them all out at one time. It is simply a matter of personal choice and what seems best.

At RBGE we tend to prick out half the batch and place them in small plug trays and once the roots are seen coming out of the bottom of the trays they are replanted into individual pots. Once this has been done successfully the rest are pricked out. The compost used is the same as that used for seed sowing but we add a bit more leaf mould. Once plants have been pricked out it is important to keep a close watch on them. If the weather is very hot and sunny then the seedlings need to be shaded with netting.

\section{DISEASES}

Meconopsis seedlings are prone to damping off but this can be cured with a fungicide spray. Aphids can also cause problems, and care must be taken when spraying young seedlings with pesticide as this can cause scorching of the leaves and in extreme situations can even kill the seedlings. One way to prevent this is to use a compost containing a pesticide such as imidocloprid (brand name Intercept) as this helps to prevent infestation from aphids or damage from vine weevil.

\section{SEED STORAGE}

To store Meconopsis or indeed any other seed for an indefinite period of time (for use in a botanic garden collection situation rather than in a gene bank for conservation purposes) requires some special attention. Seed needs to be cleaned and placed in a small sealed paper bag. Plastic bags are not suitable as they are airtight and may cause the seeds to rot off. 
Once the seed is contained it then needs to be placed into an air tight vacuum such as a sealed bell jar. This is a glass jar which splits into two pieces. Silica gel is placed in the bottom of the jar. Next the seed is placed in the jar and it is important to check that it is airtight when it is sealed. Vaseline wiped round both glass edges will make a good airtight seal. This should then be left for three weeks. This process removes the moisture from the seed which means that during the next stage the seeds will not get damaged.

After the allotted time seed can be placed into foil bags before placing in a freezer at $19^{\circ} \mathrm{C}$. However, it is important to make sure that the packets are stored in a plastic container. If this process is followed then seed should last from 15-25 years.

At RBGE we started our short-term seed bank in the 1980's and we still have original seed. $100 \%$ germination never occurs but $50 \%$ to $70 \%$ is about average. It is very important not to mix batches of seed and so each batch is kept separate and are meticulously labelled.

\section{REFERENCES}

GREY-WILSON, C. (2006). The true identity of Meconopsis napaulensis D.C. Curtis's Botanical Magazine 23 (2): 176-209.

TAYLOR, G. (1934). An account of the genus Meconopsis. New Flora and Sylva, London. 
